\title{
The Concept of Spiritual Tourism
}

\author{
Mochamad Novi Rifa'ia, 1*, Mohammad Kamaludin ${ }^{\mathrm{b}, 2}$, \\ ab Universitas Muhammadiyah Malang, Jl. Raya Tlogomas 246 Malang, 65144, Indonesia \\ ${ }^{1}$ novirifai@umm.ac.id;2 kamal@umm.ac.id \\ *Corresponding Author
}

\begin{tabular}{l}
\hline INFO ARTIKEL \\
\hline Sejarah Artikel: \\
Diterima: 8 Februari 2021 \\
Direvisi: 2 Maret 2021 \\
Disetujui: 23 Maret 2021 \\
Tersedia Daring: 10 April 2021 \\
\hline Kata Kunci: \\
Keagamaan \\
Konsep \\
Pariwisata
\end{tabular}

\begin{abstract}
ABSTRAK
Komunikasi transendental dapat terlihat oleh banyak orang di objekobjek wisata yang ada di lingkungan sekitar kita, seperti upacara kehamilan, kelahiran, sunat, pertunangan, pernikahan, ucapan syukur dan kematian. Melalui penelitian ini para peneliti ingin mengeksplorasi nilai-nilai spiritual yang menjadi obyek pariwisata. Penelitian kualitatif ini akan mengungkap fokus kajian nilai spiritualitas pariwisata dalam mengembangkan konsep wisata spiritual berdasarkan kegiatan pariwisata yang telah dilakukan dengan berbagai atraksi. Jenis penelitian ini merupakan penelitian kualitatif dengan menggunakan pendekatan deskriptif-filosofis. Penelitian ini menggunakan pendekatan deskriptif karena bertujuan untuk mengungkap konsep wisata spiritual yang tepat untuk wisata ramah muslim. Nilai spiritual pariwisata dalam Islam adalah pendekatan yang dilakukan oleh manusia kepada Allah SWT dalam menjalankan kegiatan pariwisata. Upaya yang dilakukan adalah menjauhkan haram dan melaksanakan yang halal, baik dalam aktivitas makanan maupun pariwisata. Konsep wisata spiritual yang dihadirkan adalah dengan selalu menggabungkan 4 (empat) elemen dalam menjalankan aktivitas, keempat elemen ini adalah pelaku pariwisata, keberadaan atau kekuatan Allah SWT dalam setiap aktivitasnya, kebijaksanaan Sumber Daya Manusia penyedia layanan, dan keharmonisan, serta kondisi alam lingkungan yang mengarahkan kepada getaran jiwa atas kehadiran Sang Pencipta di setiap langkah.
\end{abstract}

\begin{tabular}{|c|c|}
\hline & ABSTRACT \\
\hline $\begin{array}{l}\text { Keywords: } \\
\text { Spiritual } \\
\text { Concept } \\
\text { Tourism }\end{array}$ & $\begin{array}{l}\text { Transcendental communication is seen by many people in tourism objects } \\
\text { in our surroundings, such as ceremonies of pregnancy, birth, circumcision, } \\
\text { engagement, marriage, thanksgiving and death. Through this research, } \\
\text { researchers want to explore spiritual values in tourism. This qualitative } \\
\text { research will reveal the focus of the study of the tourism spirituality value } \\
\text { and develop the concept of spiritual tourism based on tourism activities } \\
\text { that have been carried out with various attractions. Thus, the type of } \\
\text { research is qualitative research, using descriptive-philosophical } \\
\text { approaches. This study uses a descriptive approach because it aims to } \\
\text { disclose the spiritual values of tourism. In the other hand this study also } \\
\text { analyzes the right concept of spiritual tourism for Moslem friendly } \\
\text { tourism. The spiritual value of tourism in Islam is an approach taken by } \\
\text { humans to Allah SWT in carrying out tourism activities. The efforts taken } \\
\text { are to avoid the haram and the conduction of the corruptones, both in food } \\
\text { and tourism activities. The concept of spiritual tourism that is presented } \\
\text { always combines } 4 \text { (four) elements in conducting activities, these four } \\
\text { elements are tourism actors, the existence or power of Allah SWT in each } \\
\text { of its activities, the wisdom of service providers, harmony and the } \\
\text { atmosphere of natural environments thrilling the tourist actors to the The } \\
\text { Creator in each of their steps. }\end{array}$ \\
\hline
\end{tabular}




\section{Introduction}

The fast flow of change brings great changes to human life. Everything demands fast if humans are not good at bringing themselves to the change. When all changes, then humans must not forget the divine values of their daily lives, including when someone travels for tourism.

The tourism journey itself has never been taken away from human life since the beginning, because by moving people are living, growing and developing. In the process of tourism itself actually a human being presents divine values. Today many people think that tourism is merely fun activities, this opinion is refuted if we refer to the meaning of tourism in accordance to the tourism law in 2009, which said that tourism was a travel activity carried out by a person or group of people by visiting the location certain to do recreation, personal development, or learn tourism attraction in a certain period of time.

When referring to the meaning of tourism above, basically the prophets and their followers are tourists, because they also made a meaningful journey by becoming explorers and traders. It is amazing that the Messenger of Allah and his companions must have the values of worship in every tourism trip carried out, because every trip carried out was intended to be true from the start. From this point of view, it appears that tourism travel is not new to humanity. Even now, according to Timothy \& Olsen (Jaelani, 2017), religious tourism with spiritual motivation has become widespread and popular in recent decades, occupying an important segment of international tourism and has grown substantially in recent years..
The tourism sector is one of the important sectors for economic growth. This can be seen from regions or countries that are lack of mineral resources, they generally will increase the tourism sector as their main source of income, for example Bali. Regions whose tourism has advanced, their community welfare and regional development will also advance. Tourism itself is part of the culture of a society related to the way they spend leisure or vacational time. In the other hand nowadays tourism or recreation has become a necessity of life for modern people. By doing tourism someone will have free time to gather and spend time with his relatives or loved ones by purpose to add insight to the knowledge of children or simply to eliminate boredom from daily routine (Intan, 2017).

The tourism model that continues intensifying of course will also influence people's lifestyles and culture. All kinds of tourism activities are expected to be able to contribute to the tourism area financially. However, more than that tourism travel carried out by someone should also contribute to the carrying of self-value to prioritize The Creator.

When someone seeks the greatness of The Creator, the Kauniyah verse about the greatness of His creation would never be enough if it was written even by the sea water used as the ink. (QS. Alkahfi 109) then there is really nothing in His creation that is useless and denied (QS. Ali Imron 190). Therefore, it is indeed a happy person if someone is able to present the values of spirituality in his daily activities, including tourism. 
Dinitri (2018) in his article entitled Potential Development of Spiritual Tourism in Sindangbarang Cultural Village, Bogor, revealed that based on the results of the study it was found that the element of spiritual tourism in the form of attractions, places and visitor motivation could be a strength for Sindangbarang Cultural Village in developing tourism. In contrast to the previous research which focused on the objects in Sindangbarang the contraction provided, this study also wanted to reveal the spiritual values revealed from within tourism (Dinitri, 2018).

Research by Sari, Wajdi, \& Sari Narulita (2018) wrote that increasing spirituality is a process of change from bad to better by constantly carrying out orders and avoiding the prohibition of Allah consistently with the guidance of harmonious values of faith to recognize and understand own feelings, other people, motivate themselves, and be able to manage emotions in dealing with others (Dinitri, 2018). In contrast to previous research that focused on the location of the study at ArRiyadh Kwitang Mosque Sacred Madkam, this study more generally views spiritual values from all aspects of tourism and tourism locations.

Research by Biroli, Kartono, \& Demartoto (2018) wrote about the rationality of Pilgrim Tourism (Phenomenological Study of Tourism in the Pilgrim Tourism Area in Gunungpring Village, Muntilan District, Magelang Regency). His research revealed that there were existential tourists and recreational tourists. Existential tourism is a tourist who consciously prioritizes spiritual values in every activity (Biroli et al., 2015). The research focused more on one location in Muntilan, and is different from this study that measures spiritual values of travel from all aspects and is not adrift in one specific location.

In the study of Variety of Potential Demand for Spiritual Ecopourism in Bogor Communities, written by Pratiekto (2017) it concluded that spiritual tourism had the potential to be marketed to consumers at all income levels, from low-income to highincome (Pratiekto, 2017). Being a supporter to reveal the spiritual values of community income does not affect spiritual tourism activities.

While Komang Deya Pradnyana's writing, I Made S and I Putu S (2016) in a study entitled Planning Spiritual Tourism Packages in the Gunung Rinjani National Park Area reveals that spiritual tourism has a conservational purpose or understanding and deepens back into itself and understands that spiritual meaning (Pradnyana et al., 2016) which revealed the values of spirituality on Mount Rinjani, researchers wanted to disclose the value of spirituality that could be found in many tourisms, so that the writer did not focus only on one object.

This literature research wants to explore the important value of tourism, so that tourism is seen not only as a fun activity, but also it has deep values about life relationship between The Creator, nature, culture and humans themselves.

The concept of tourism that is connected with divine spiritual values is what will maintain the harmony of the relationship between The Creator, universe and mankind themselves. The level of spirituality of each person is different and often experiences ups and downs. When a person experiences an increase in the level of spirituality he undergoes a peaceful state of mind, by which he is able to adjust to various situations, to avoid mental illness, to deal with any problems, and to pops up the best use of the potential within himself. Whereas when the level of spirituality decreases, it will lead to emptiness of heart, especially in the remembrance of the true purpose of life in the world. Usually it can drive to negative traits such as being naughty, liar, fond of disturbing and persecuting others, offending and hurting other people's feelings (Selamat, 2005). So by the implementation of spiritual understanding in tourism it is hoped to increase the value of someone's quality to always live with Allah SWT. Therefore, this research will try to uncover the spiritual 
values of tourism and the spiritual concept of tourism.

\section{Method}

This qualitative research will bare the focus of the study of the tourism spirituality values and develop the concept of spiritual tourism based on tourism activities that have been implemented with various attractions. Thus, this type of research is qualitative research, using descriptive-philosophical approaches.

This study uses a descriptive approach because it aims to reveal the spiritual value of tourism. In the other hand this study also analyzes the concept of spiritual tourism that is right for Moslem friendly tourism.

Data analysis in this study used qualitative one. According to Moleong (2014), qualitative data analysis is an effort realized by working with data, organizing data, sorting them into manageable units, synthesizing, and finding patterns, discovering what is important and what is learned, and deciding what can be told to others. More briefly, these steps include: recording, classifying, and forming a framework of thought processes.

In the early stages the researcher will convey the spiritual concept, and the standard will be used to see and analyze various kinds of tourism attractions so that divine values will emerge.

The data used are primary data which are directly drawn from observations at the location and secondary data are from existing literature, where data are obtained from documentation taken from various sites related institutions, books, and published articles in correspondence to the problem studied. The writing of scientific papers begins with collecting data and information related to the problem to be analyzed. The data and information that have been collected are then evaluated to provide the accuracy of the information and analysis that will be written.

The next step is to analyze the data and information that have been collected. The analytical method used is descriptive analysis, which is a series of procedures used as problem solving efforts investigated by describing the state of the subject or object of tourism that will be examined at the moment based on facts that appear or as they are.

After analyzing the data, the next step is to provide alternative solutions to solve existing problems about the values and spiritual concepts of tourism, then proceed to the last stage, namely making conclusions and suggestions based on the results of the analysis that has been done.

\section{Result and Discussion \\ 3.1 Spirituality}

Priatno explained that spirituality was worship and devotion to Allah SWT, by living in harmony with the teachings of Allah SWT brought by His Messenger. Then it can be interpreted that people who undergo spirituality consistently are people who believe, i.e. people who always cling to the rope of Allah SWT (Martokoesoemo, 2007). The relationship between creatures and The Creator individually or collectively in carrying out religious values is called transcendental communication. it is the communication taking place inside in respond to something outside oneself, which is realized by the individual because of an awareness of a divine essence beyond his existence (Thadi, 2017). As perpetrators of life, humans try to uncover the signs and symbols of divine values that have been presented by Allah SWT throughout all of His creations (Sari et al., 2018).

Delgado (Hanna, 2006), identified four characteristics of spirituality that are considered important; 1) Spirituality requires a belief system (willingness to believe) and what is believed to be truthful (belief in higher power or the existence of a religion based on core beliefs), 2) Spirituality involves the individual's condition in the search for meaning and purpose of transcendent attachment or individual mission of calling for destiny or fate and shifting from material values to idealistic values, 3) Spirituality includes 
consciousness attachment to other people obtained through self-reflection. In nonreligion contexts, this condition can be explained as a sense of awe, appreciation and respect. In the context of religion, it includes a high relationship with God which is connected through prayer and meditation. Spirituality involves the process of reconciling beliefs and practices when individuals are confronted to difficulties and conditions of pain, 4) Spirituality is the belief that someone can fathom beyond his limits in a higher dimension, the desire for truth and purity and belief that one can resolve difficulties, losses and pain with that belief.

Spiritual value itself can be obtained through transcendental communication, which is to make people aware of religious needs and recognize religion as a problem solver in all forms of human activities. Transcendental communication is a form of intrapersonal communication that occurs within oneself with something outside himself whose existence is realized by the individual. In other words, transcendental communication is communication that takes place between the individual and something that is magical.

According to Mario Beauregard and Denyse O'Leary, the researchers and authors of the Spiritual Brain argue that spirituality means a thinking experience which brings involvement into contact with God (in other words, not only experiences that feel meaningful). Ruth Beckmann Murray and Judith Proctor wrote that the spiritual dimension tried to be harmonious with the universe, and strived for answers about the infinite, and came into focus when a person faced emotional stress, physical illness, or death (Ardian, 2016).

In fact, spirituality is an important aspect of human life that is why social workers in providing psychosocial services as their core services should not be separated from the issues and context of spirituality. A recent study by Rapp (2010) has shown that religion and spirituality are strengths rather than pathology (Syamsuddin \& Azman, 2012).

According to Ary Ginanjar Agustian, spirituality is the ability to give meaning to worship for every behavior and activity, through steps and thoughts that are natural towards a whole person (hanif) and have a pattern of monotheistic thinking (integralistic), and rely on the principle of "only because of Allah (lillahi Ta'ala)" (Agustian, 2001).

In fact, spirituality is an important aspect of human life that is why social workers in providing psychosocial services as their core services should not be separated from the issues and context of spirituality. A recent study by Rapp (2010) has shown that religion and spirituality are strengths rather than pathology (Syamsuddin \& Azman, 2012).

In our surroundings, a lot of transcendental communication can seen in the community, such as ceremonies of pregnancy, birth, circumcision, engagement, marriage, thanksgiving and death. By doing transcendental communication activities, actors will express to themselves and the community the feelings in the form of verbal and nonverbal. When undergoing the ritual, the perpetrator will feel comfortable with the ritual actions.

Various facts and history have noted the magnitude of the role of spirituality in building political and economic institutions and spurring the level of economic growth and success of development (Pratiekto, 2016). According to Saefulah quoted by Anniza, there are five human goals to communicate with God, namely: increasing faith and taqwa, improving the quality of worship, improving moral quality, achieving essential peace, seeking for safety in the current world and the hereafter (Annizarizki, 2018)

Pratiekto (2016) also revealed that various dynamics to obtain and spend income, property and material wealth are included as an important part of the journey of human life which is also inseparable from the influence of spirituality. On the one 
hand, spirituality is often a barrier or even a restraint on the orientation of human material desires to continue to collect and spend wealth. Somehow on the other hand, it is undeniable that spirituality is also a social driver that has a strong influence on economic behavior at the level of individuals and communities, especially in the aspect of consumption (Pratiekto, 2016).

In addition to being a guideline, spirituality also influences consumptive patterns through the teachings of future life after death (after life) so as to encourage religious people not only to allocate secular time and assets for consumption but also for various forms of consumption including the religious one which is intended for the sake of the hereafter for various commodities or goods and services that embody religious drive (Pratiekto, 2016).

Based on the theory of Koentjaraningrat (1974), the results of the analysis of spiritual values include: 1) surrendering, submission and obedience to God Almighty; 2) a life full of glory; 3) inner feelings that have something to do with God; 4) feelings that correlates to prayer.

\subsection{Tourism}

Meanwhile, tourism is defined as the movement of people temporarily and in short periods of time to destinations outside the place where they usually live and work. Humans individually or in groups go to a place to meet their psychological needs seeking entertainment, pleasure and forgetting daily fatigue from work routines. The more people are doing tourism; the more it will grow rapidly both at the local, national and international levels. Tourism infrastructure is developing to serve tourists. The forms and attractions of tourism will also encounter rapid development. In harmony with human needs, tourist destinations also began to range from natural, cultural, culinary to religious tourism (Annizarizki, 2018).

The tourism potential can be divided into 3 parts, namely:
1. Cultural potential is the potential that grows and develops in the community, both customs, livelihoods, arts and culture.

2. Natural potential is the potential that exists in society in the form of physical and geographic potential such as nature.

3. Human potential is the potential owned by human that can be used as a tourist attraction, such as through staging dances / staging cultural arts of an area.

From the above explanation, it can be interpreted that tourism potential is an advantage of an area that makes it attractive to tourist lovers. This potential can be in the form of human-made attractions or natural attractions formed by nature.

\subsection{Spiritual Value of Tourism and Tourist Attractions}

Spiritual tourism is a new trend in the world of tourism whose tendency continues to increase. This type of tourism is very potential to be developed and of sufficient quality, because in practice this type of tourism highly respects local cultural traditions, loves nature and the environment, and most of its tourists come from educated circles (Dinitri, 2018).

The emergence of the term spiritual tourism according to Dinitri quoted from Sukidi (2001), can not be separated from the existence of the New Age Movement. The New Age is a portrait of an age that blends Western rationalism with Eastern spiritual mystics. The main characteristic of this era is the rejection of formal religion, because it is seen as inclination to curb individual freedom. Spiritual peacefulness can be immersed and enjoyed by penetrating religious boundaries. The essence of all religions is believed to be the same, and all reality is seen as the emanation of God. Activities delivered by The New Agers are 
interfaith spiritual tours (Sukidi, 2001). This changing era will certainly change people's approach to religious needs.

According to Dinitri (2018), Barkemen said that spiritual tourism in general were all forms of tourism, which included spiritual and physical travel. The interaction of the body and mind was also emphasized by Brämer, who considered spirituality as a union of head, heart and body, which could be achieved primarily by physical movements in nature and on the other hand saw motivation for spiritual or religious tourism as part of culture-oriented tourism.

As quoted by Dinitri (2018), she stated that actually spiritual tourism had been present on earth since centuries ago. Spiritual tourists travel to many places to seek for peace and harmony, and they are mostly educated people, caring about culture, caring for nature and the environment, and not disturbing anyone.

Based on the opinions from several sources above, tourism initially seems to follow the view that spiritual tourism is a tour to seek spiritual experiences that do not see a particular religion, but are more focused on seeking peace and harmony. If it is viewed from Islamic perspective then it is Islamic approach.

\section{Attraction Elements}

R. Conrady and M. Buck in his book Trend and Issues in Global Tourism 2011, spiritual tourism activities are categorized as follows:

a. Interaction with nature and exercise: pilgrimages, hiking, meditating, walking.

b. With counseling: talk with pastoral worker; talk with shaman; talk with spiritual coach, etc.

c. With music: singing mantras, tones.

d. With creativity: meditating, painting, ikebana.

e. With physical exercises: yoga, tai chi, meditative dances, circle dances. f. With spiritual exercises: spiritual exercises (in silence), contemplation, meditating, trips to shamans.

\section{Place Elements}

The destinations of spiritual tourism based on place classifications explained by Shackley in Blackwell in Dinitri (2018) are as follows:

a. Natural phenomena (lakes, mountains, islands, gardens, etc.)

b. Originally made for religious purposes

c. Buildings with religious content

d. Special events of religious importance that are held in non religious places

e. Places are built on secular thoughts that are relevant to tragic stories or those events that are particularly political. For example, Nelson Mandela's prison on Robin island

\section{Motivational Elements}

Spiritual tourism is based on two things as stated by Wilson and Harris, and Little and Schmidt (2006) in (Maulana, 2014):

a. The "Self". Factors of the "self" or self that is usually used to seek for selfidentity and self-recognition usually dominate this type of tourism.

b. The "Other". Factor "the other" or that comes from outside a person can be in the form of culture, environment and others. There will be no self without any other. By being aware of this, you are motivated to open your heart more and expand your mind to erode tension that will dynamically emerge from both dimensions.

Pechlaner in Conrady according to Dinitri (2018) categorizes the motivation of tourists to take a spiritual journey due to following factors:

a. Religion: At the level of social needs according to Maslow Needs, 
participation in spiritual tourism can give rise to a sense of belonging towards a particular religious group, especially those with religious beliefs who support or favor pilgrimage activities.

b. Culture: Motivation of spiritual tourists is also due to cultural factors that exist to recognize and understand the procedures and culture of the region that is owned or the culture of other regions, such as: the habits of the people, buildings, music, dances and so on, resulting in spiritual values in understanding the culture.

c. Health: motivation of spiritual tourists according to Pechlaner in Conrady is also triggered by reasons of mental and physical health. According to Conrady, currently health tourism is included in the component of spiritual tourism. In ancient times there were activities where mineral water sources were considered to have the efficacy to cure diseases or the place to do meditation or yoga for the peace of mind and body.

d. Looking for the deepest meaning and seeking self (Quest for a Deeper Meaning and Identity): According to Maslow, spiritual tourism can at least provide psychological stability and calm by maintaining continuity of hope, especially for those who experience depression and despair due to the stresses of life.

A spiritual journey in the form of spiritual tourism is one of the religious commodities that are of economic importance. In relation to consumption, spiritual tourism can even attract the culprit to make relatively large or significant expenditures when compared to the income they have. For example, in the Muslim community, where the command of pilgrimage to the holy land in the form of a Hajj ritual is an obligation for those who are capable, while the ritual of travel in the form of Umrah is recommended and rewarding to do (Pratiekto, 2016).

From the perspective of the demand side, the large demand for spiritual tourism activities as religious commodities that are considered important in almost all religions implies a high opportunity to optimize this kind of tourism activities. This fact leads people to come to consideration that from the perspective of the supply side many parties will agree that the values of spirituality and religiosity possessed by the Indonesian nation as a pluralistic and richly diverse nation have the potential to be marketed in a spiritual or religious ecotourism umbrella (Pratiekto, 2016).

The rich potential of the spirituality of Indonesia is not only in the form of objects and spiritual tourist attractions, but also the socio-cultural environment which is very supportive for tourism development. As such, it is a challenge for all parties to market the potential of spiritual tourism in order to create added value and multiple benefits for the local economy and create a sense of appreciation and pride to the nation's culture so as to improve the quality of the culture of society as a whole (Pratiekto, 2016).

\subsection{Concept of Tourism Spirituality}

Bringing up spiritual values in tourism is a concept that should exist, so that the happiness sought by humans is attached until the end. The existence of the Khaliq is sometimes detached from the hustle and bustle of human activity itself, so that the relationship between The Creator and the creature does not seem to exist, even though since mankind was conceived, when the spirit was blown by The Creator the relationship continued until the end of life. (QS Shaad 72). 
The dialogue of the existence of God Almighty is also continued to reinforce the position of The Creator and creature, but the affection of humans as descendants of Adam is often negligent about the existence of The Creator and His power. (Qur'an 7: 172).

The spirit of divinity is also honed in human relations with other humans. Like the command of God's word in QS. Al-maidah 32 which instructed human to respect the lives of others as the manifestation of respect for human rights and glorification to humans.

In the Surah Al-baqarah ; 83 Allah SWT also affirms the obligation to do good to other human beings. The order is also accompanied by an order for tawhid. This verse seems to reveal that worshiping Allah SWT is not perfect, before the person is able to do good to other humans.

The emergence of spirituality will also appear in human relations with other creatures created by Allah SWT, namely like animals, plants and the environment around the subject of the perpetrator. The subject of the offender will feel alive in him with good behavior towards other beings. Bad man's behavior such as destroying nature or killing animals carelessly (QS. Arrum 41), of course besides causing damage to the ecosystem, but also can kill the conscience, which actually makes himself more distant from his The Creator.

Have a check on the pattern of tourist relations with spirituality that must be realized in spiritual tourism, then the concept of linkages should emerge between the 4 (four) elements as depicted in the figure 1 below:

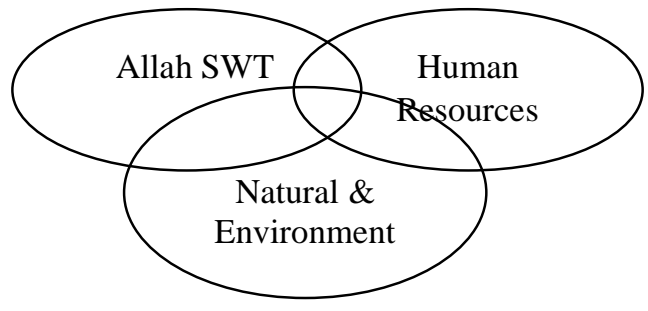

Figure 1 Concept of Spiritual Tourism
From the picture above it can be seen that the relation 4 (element) is inseparable, and the image slices show a relationship that cannot be separated by anything. The totality of togetherness must absolutely be carried out by not leaving one of the elements. Before the concept is implemented, of course tourists must intend sincerely in the heart because of Allah alone, also must instill a divine mindset in the head and all members of the body must act in a properly suitable manner with the Divine Rabbi guide. Then the element presents the existence or power of Allah SWT in each of its activities, the wisdom of the Human Resources of the service provider as other humans who interact, and the natural conditions of the environment that are harmonious and lead to The Creator.

The final target of the concept presented above is of course only for increasing piety, the quality of worship, morals, peace of mind and world salvation. This goal will benefit the next generation. Compared to the concept of recreational tourism, spiritual tourism will provide both physical and spiritual effects.

\section{Conclusion}

The spiritual value of tourism in Islam is an approach taken by humans to Allah SWT in carrying out tourism activities. The efforts taken are to avoid the haram and the conduct of corrupt ones, both in food and tourism activities.

The concept of spiritual tourism that is presented always combines 4 (four) elements in conducting activities. These four elements are tourism actors, the existence or power of Allah SWT in each of its activities, the wisdom of service providers, and the natural conditions of harmony and direction the thrill of the tourist actors to the The Creator in every activity.

\section{References}

Agustian, A. G. (2001). Rahasia Sukses Membangun Kecerdasan Emosi dan 
Spiritual ESQ. Arga Wijaya Persada.

Annizarizki. (2018). Manajemen Wisata Religius Kesultanan Banten (Bauran Komunikasi Pemasaran dalam Meningkatkan Jumlah Wisatawan). Nyimak Journal of Communication, 2(2), 187-205.

Ardian, I. (2016). Konsep Spiritualitas dan Religiusitas (Spiritual and Religion) dalam Konteks Keperawatan Pasien Diabetes Melitus Tipe 2. Nurscope, 2(5), 1-9.

Biroli, A., Kartono, D. T., \& Demartoto, A. (2015).

RASIONALITAS

WISATAWAN WISATA PILGRIM (Studi Fenomenologi Terhadap Wisatawan Di Kawasan Wisata Pilgrim Desa Gunungpring, Kecamatan Muntilan, Kabupaten Magelang). Jurnal Analisa Sosiologi, 4(2), 98 -114.

Dinitri, S. (2018). Potensi Pengembangan Wisata Spiritual Di Kampung Budaya Sindangbarang, Bogor. Jurnal Hospitality Dan Pariwisata, 4(2), 95112.

Doi: http://dx.doi.org/10.30813/.v4i2.1403

Hanna, H. H. (2006). The Influence of SelfEfficacy and Spirituality on Self-Care Behaviors and Glycemic Control in Older African Americans With Type 2 Diabetes. ProQuest Information and Learning Compant , 22-24.

Intan, K. (2017). Upaya Indonesia Meningkatkan Daya Saing Muslim Friendly Tourism (MFT) Diantara Negara-Negara OKI tle. Jurnal Ilmu Komunikasi Univeristas Riau, 4(2), 112.

Jaelani, A. (2017). Industri Wisata Halal di Indonesia: Potensi dan Prospek. Munich Personal RePEc Archive. https://mpra.ub.unimuenchen.de/id/eprint/76237

Koentjaraningrat. (1974). Kebudayaan, Mentalitet, dan Pembangunan.
Gramedia.

Martokoesoemo, P. H. (2007). Spiritual Thinking. Mizania.

Maulana, A. (2014). Strategi Pengembangan Wisata Spiritual Di Kabupaten Badung, Provinsi Bali. Jurnal Kepariwisataan Indonesia, 9(2), 120.

Moleong, J. L. (2014). Metode Penelitian Kualitatif , Edisi Revisi. PT Remaja Rosdakarya.

Pradnyana, I. K. D., Sendra, I. M., \& Sudana, I. P. (2016). Perencanaan Paket Wisata Spiritual di Kawasan Taman Nasional Gunung Rinjani. Jurnal IPTA, 4(1), 1.

Pratiekto, P. E. (2016). Ragam Permintaan Potensial Terhadap Ekowisata Spirtual Pada Masyarakat Bogor. Media Konservasi, 21(3), 242-251.

Sari, N. I., Wajdi, F., \& Narulita, S. (2018). No Title. Jurnal Studi Al-Qur'an, 14(1).

Selamat, M. I. (2005). Penawar Jiwa \& Pikiran. Kalam Mulia.

Sukidi. (2001). New Age wisata Spiritual Lintas Agama. Gramedia Pustaka Utama.

Syamsuddin, \& Azman, A. (2012). Memahami Dimensi Spiritualitas dalam Praktek Pekerjaan Sosial. Jurnal Informasi, 17(2).

Thadi, R. (2017). Komunikasi Transendental: Sholat Sebagai Bentuk Komunikasi Transendent. Jurnal Syi'ar, 17(2). 